\title{
ONLINE HOAXES, EXISTENTIAL THREAT, AND INTERNET SHUTDOWN: A Case Study of Securitization Dynamics in Indonesia ${ }^{I}$
}

\author{
Antony Lee \\ Kompas Newspaper, Indonesia \\ Email: antony.lee@kompas.id
}

\begin{abstract}
As one of the countries in the world with the highest growth of internet users, Indonesia is experiencing a rapid growth in social media usage. Some use social media for networking but some others use it to spread hoaxes, fake information, or disinformation. During presidential election in Indonesia in the period from 2017 to 2019, hoaxes and disinformation were widely circulated through social media and instant messaging. This phenomenon has triggered heated public debates on the nexus between digital spaces and security, which include how the online disinformation has threatened Indonesian security. For example, hoaxes were represented in the public sphere as an existential threat to Indonesian unity. Immediate question regarding this phenomenon is: why are online hoaxes and fake information represented in public spheres as a security threat? This paper argues that as a response toward the increase of online hoaxes, there were securitizing moves made by political elites and special agencies in Indonesia before and in the aftermath of the 2019 Indonesian presidential election. Employing discourse analysis of selected relevant news articles around the period of 20I7-20I9, this paper analyses the dynamic of the securitization of online hoaxes in Indonesia. Grounded within Securitization Theory, this paper analyses; the facilitating condition; the triumvirates of securitizations, which are the securitizing actors, the threats posed by hoaxes, and the audiences; as well as extraordinary measures executed to handle the threats; internet throttling and internet shutdown when necessary.
\end{abstract}

Keywords: Digitalization, Throttling, Shutdown, Hoax, Internet, Securitization Theory, Indonesia

\begin{abstract}
Abstrak
Sebagai salah satu negara dengan pertumbuhan pengguna internet tertinggi di dunia, Indonesia mengalami pertumbuhan penggunaan media sosial yang pesat. Beberapa orang menggunakan media sosial untuk berjejaring, tetapi beberapa orang yang lain menggunakannya untuk menyebarkan hoaks, informasi palsu, atau disinformasi. Selama pemilihan presiden di Indonesia pada periode 2017 hingga 20I9, hoaks dan disinformasi diedarkan secara meluas melalui media sosial dan pesan instan. Fenomena ini telah memicu perdebatan publik yang memanas tentang hubungan antara ruang digital dan keamanan, yang mencakup bagaimana disinformasi daring telah mengancam keamanan Indonesia. Misalnya, hoaks direpresentasikan di ruang publik sebagai ancaman eksistensial terhadap
\end{abstract}

I This paper was prepared to be presented at the 2020 OBIC Conference on "Megatrends in Asia: Digitalization - Security and Foreign Policy Implications", on 4-5th May 2020 at Budapest Business School, Faculty of International Management and Business, Hungary. However, due to Covid-19 pandemic, the conference is postponed to May 2021. 
persatuan Indonesia. Pertanyaan yang segera muncul mengenai fenomena ini adalah: mengapa hoaks daring dan informasi palsu direpresentasikan di ruang publik sebagai ancaman keamanan? Makalah ini berargumen bahwa sebagai tanggapan terhadap peningkatan hoaks daring, ada langkah-langkah sekuritisasi yang dilakukan oleh elite politik dan agensi khusus di Indonesia sebelum dan setelah Pemilihan Presiden Indonesia tahun 20I9. Dengan menggunakan analisis wacana terhadap artikel berita relevan sekitar periode 20I7-2019, makalah ini menganalisis dinamika sekuritisasi hoaks daring di Indonesia. Beralas dalam Teori Sekuritisasi, tulisan ini menganalisis; kondisi yang fasilitasi; triumvirat sekuritisasi, yang terdiri dari aktor sekuritisasi, ancaman yang ditimbulkan oleh hoaks, dan audiens; serta tindakan luar biasa yang dilakukan untuk menangani ancaman; pembatasan internet dan penghentian internet bila perlu.

Kata kunci: Digitalisasi, Throttling, Shutdown, Hoax, Internet, Teori Sekuritisasi, Indonesia

\section{INTRODUCTION}

For many Indonesians, 20I9 could be acknowledged as a challenging political year. For the first time, the archipelagic state held a concurrent parliamentary and presidential elections, in which a person had to cast five ballots in a single election day; one ballot each for the house of representatives at national, provincial, and district levels, as well as for the regional representative and the presidential election. In previous elections, the legislative election was conducted a few months before the presidential election. This new democratic engineering has made Indonesia's election one of the biggest and the most complicated one-day election in the world (Surbakti, 20I7). However, it was not the procedural electoral processes that made 2019 the most exhausting year. It was the influx of hoaxes, fake information, and disinformation that created a gloomy ambiance for Indonesian. Families were divided, friends became foes, and neighbours stopped talking to each other. Those were arguably triggered by political polarization, which was, to some extent influenced by the widespread of hoaxes, ranging from defamation of presidential candidates, to dispersal of contentious religious and racial narratives.

Hoaxes and fake information are not novel phenomena. In Indonesia, for example, during 1998-1999, there were widely spread hoaxes about black magic sorceresses in Banyuwangi, East Java that led to the killings of many people. Besides, during the 2014 Indonesian Presidential Election, there was a print publication named "Obor Rakyat" or in English translation; People's Torch, that published articles containing fake information about one of the presidential candidates, while camouflaging itself as a mainstream publication (Gunawan and Ratmono, 2018). However, the recent advance of technological communication and significant growth of internet penetration have brought the impact of fake information to the next level. Internet enables people to easily manipulate and fabricate contents, while at the same time facilitate the exponential scale of fake information distributions, especially when fake information is "shared by uncritical publics" (Ireton and Posetti, 20I8, p. 15).

What happened following the spread of hoax and fake information during period of the 2019 Indonesian election was that political elites started to denote hoaxes and fake information as a significant threat to the country. In public speeches as well as in press conferences, several elites describe hoaxes as a pressing security concern. Discourse analysis toward news articles samples show that elites - within the government as well as non-governmental elites - consider hoaxes and disinformation, among other things, as "threat to security and public order", "inciting political instability", "the act of terror", "threatening social cohesion", "creating public confusion", "disintegrating the nation", as well as "delegitimating democracy".

Online hoax and fake information have gained a plethora of attention from academicians worldwide. Based on her research in India, Swati Bute (2014) argues that social media, on the one hand, can facilitate activisms, but on the other hand can also led to social conflicts, especially when hoax and disinformation touch upon a sensitive issue, such as identities. Pertaining to the issue of security, Ravi Gupta and 
Brooks Hugh underline that social media can affect global security in positive, negative, and ambiguous ways. Social media can be used to combat violence, but at the same time can also be used by rioters, terrorists, and criminals to help them do what they aim to do (Gupta and Hugh, 2013, p. I5). In Indonesia, studies about this issue mainly focus on the nexus of fake news and persecution (Azali, 20I7); the impact of hoax in Indonesian politics (Utami, 2018); how social media, including disinformation, influence social cohesion (Lim, 20I7; Suradi, 20I8). Several articles also approach hoaxes from the perspective of digital literacy (Yanti and Yusnaini, 20I8; Salma, 2019), and from a juridical point of view (Setiawan, 20I9; Nugroho, 2019).

Although those studies provide different perspectives on hoaxes and Indonesian societies, it can be argued that they focus more on analysing the "actual" security concern related to hoax impact on the societies. However, those studies are unable to explain the discursive process of how hoax and fake information are perceived as a security threat. Therefore, this paper tries to fill the gap by employing Securitization Theory from the Copenhagen School (Waever, I995; Buzan et al, I998; Waever, 20II), to answer the question of why online hoaxes and fake information are perceived as a security threat. In that sense, this paper argues that hoaxes and disinformation have been constructed by political elites and special agencies to be an existential threat toward the nation's unity, and they, therefore, take extraordinary measures to address this issue: internet throttling and internet shutdown when needed.

This paper is structured into four parts. The first part describes social media and internet landscapes in Indonesia, while the second part discusses the theoretical framework. Part three will discuss the dynamics of online hoax securitization, eventually, the last part will provide a brief conclusion.

\section{INTERNET LANDSCAPES, SOCIAL MEDIA, AND HOAX}

In 2000 , there were only 2 million internet users in Indonesia, which means that only less than one percent of the Indonesian population could access the internet (Lee, 20I6). However, in the past two decades, internet penetration has increased significantly. In 2018, according to a survey conducted by the Association of Indonesian Internet Services Provider, it is estimated that the internet penetration in Indonesia reached 64,8 percent of the population. This shall mean that approximately I7O million people can access the internet. This is a much bigger figure compared to that of a similar survey by APPJI a year before, claiming that internet penetration reached 54,6 percent (APPJI, 20I8). When asked about what they used the internet for, the top three responses from the respondents are; (I) instant messaging $(24,7$ percent); (2) social media (I8,9 percent), and (3) looking for information about job vacancies (II, 5 percent). Around I4,I percent of the respondents use the internet for approximately 3-4 hours a day, while 13,4 percent of them use it for 2-3 hours per day, and the others spend less than one hour up to more than 8 hours per day to access the internet (APPJI, 20I8).

Table I. The Most Visited Social Media Platforms by Indonesians

\begin{tabular}{ll}
\hline Social Media & Percentage \\
\hline Facebook & 50.7 \\
\hline Instagram & 17.8 \\
\hline Youtube & 15.1 \\
\hline Twitter & 1.7 \\
\hline Linkedin & 0.4 \\
\hline Never & 7.1 \\
\hline Others/Didn't know/Didn't answer & 7.2 \\
\hline Total & 100 \\
\hline Source; APPJI (20I8) &
\end{tabular}

Social media has influenced societies in Indonesia in both good and bad ways, which to some extent resemble Janus' faces. In ancient Roman myth, Janus is described as a god with two faces. One of the good impacts of social media is that it has facilitated the emergence of several high-profile digital activisms, namely "Coin for Prita" and "Gecko versus Crocodile" (Lim, 20I3; Priyono et al, 20I4; Gazali, 20I4). "Coin for Prita" was an online movement brought up through Facebook to help Prita Mulyasari, a mother of two, who was found guilty 
of defamation against a hospital in Jakarta. She had to pay a fine amounted to around 22,000 USD (Lim, 2013). Gecko versus Crocodile was a social movement to protect the Indonesian Corruption Eradication Commission or KPK when it clashed with the Indonesian National Police. During that time, KPK investigated high profile corruption cases (Gazali, 20I4). In addition, during the polarized 2014 Indonesian Presidential Election, online activism emerged to guard vote recapitulation processes, utilizing a Facebook group and a website. A similar movement also emerged during Indonesian concurrent local elections in 2015 and 2017 (Tapsell, 2017; Lee, 2019).

However, social media showed the other side of Janus's face. Several social conflicts in Indonesia, such as riot in Tanjung Balai, North Sumatera (thejakartapost.com, 31/07/2016), were triggered by hate speeches and fake information shared widely through social media and online messaging such as Whatsapp. In general, Hoaxes have increased significantly during the period from 2017 to 2019. According to data from the Indonesian National Police, in 2017 Police investigated I,254 fake news contents, while in 2018 , the number reached 3,884 contents (Kompas, 03/02/2019, p.2). Data on google search in Indonesia, with the query of "hoax", started to increase exponentially during 2017, 2018, and 2019, as shown in Graph I. Similarly, news articles from Kompas Newspaper and Media Indonesia online platform contain the word

\section{Graph I}

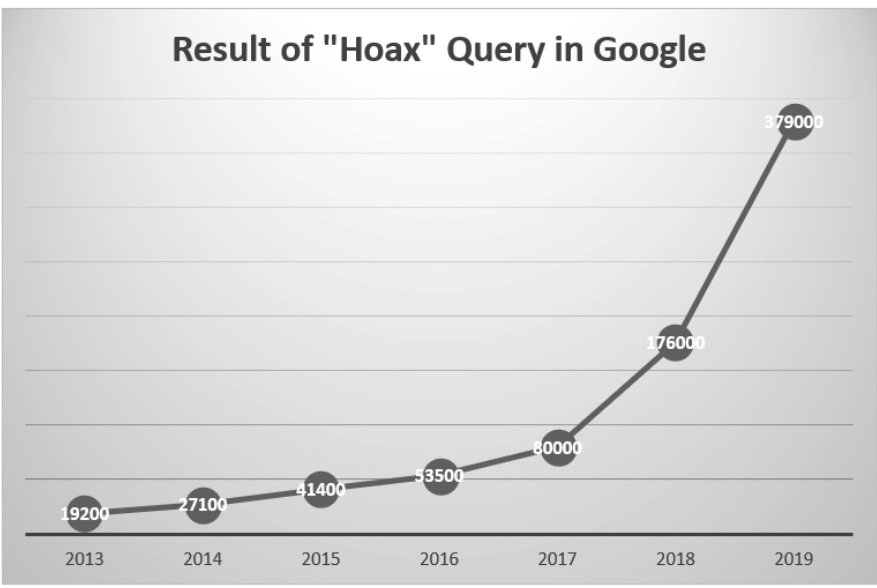

Source: Google Advance Search (2013-2019)
Graph 2.

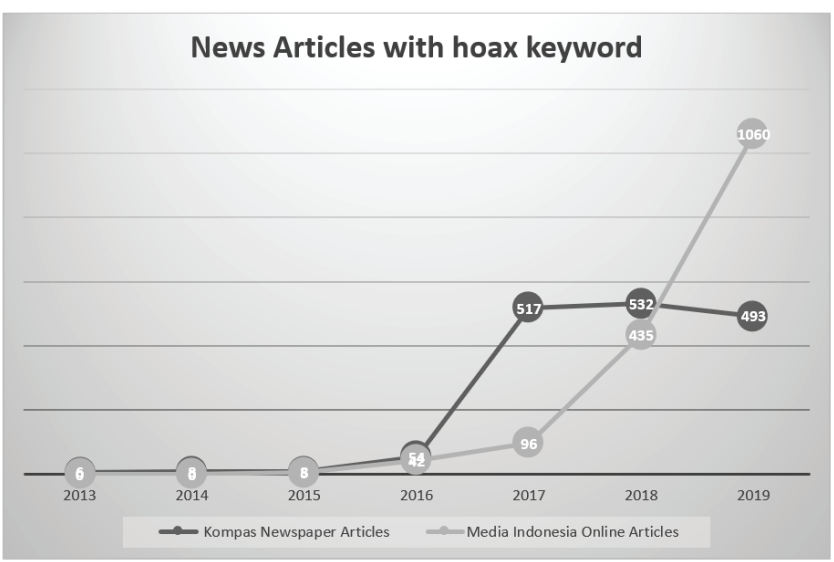

Source: Kompas Data Center and Google Advance Search

"hoaks" or "hoax" soared in 2017-20I9 (see Graph 2). The data shows that hoax started to be discussed more intensively in Indonesian public spheres in 2017.

There are at least three incidents in 2017 when hoax started to became the common public issue in Indonesia. Firstly, in 20I7, Jakarta, the capital city of Indonesia held a gubernatorial election. The incumbent candidate, Basuki Tjahja Purnama, was indicted for a blasphemy case. During the election, hoaxes and fake information were widely distributed, which consequently divided societies, not only in Jakarta - but also at national level (Lim, 20I7). Secondly, in 20I7, with some stages of the 20I9 Presidential Election commencing, the potential candidates had been discussed in public spaces, where the incumbent Joko Widodo might likely to compete with his rival, Prabowo Subianto. During the 2014 Presidential Election, Prabowo's team and Joko Widodo's team fought tooth and nails to win the election. The nation was divided even after the Indonesian Election Commission announced Joko Widodo as the winner of the election. Last but not least, since the 2016 United States Presidential Election, there has been a global debate on fake information's impact on domestic politics, especially during an election (Lee, 20I9). 
Before further discussing the nexus between social media and hoax, it is important to firstly understand what hoax and fake information mean. Merriam-Webster>s online dictionary defines hoax as "to trick into believing or accepting as genuine something false and often preposterous" (merriam-webster.com). Meanwhile, this online dictionary defines disinformation as "false information deliberately and often covertly spread to influence public opinion or obscure the truth" (merriam-webster.com). Disinformation and hoax are different from misinformation, which can be understood as simply "mistaken or misleading information" while disinformation underlines the intention of the people distributing the false information as "intentional, deliberate, or purposeful to mislead, deceive, or confuse" (Fetzer, 2004, p.23I). The deliberate falsehood distribution aims at political or economic benefit or both (Neo, 20I9). In this sense, the definition of hoax and disinformation is relatively similar, since both share similar characteristics, which are; (I) they contain false information; (2) the false information are shared consciously; (3) they are intended to decoy people.

However, Allcot and Getnzkow (20I7) as cited in Gunawan and Ratmono (2018, p. 4), state that hoaxes and fake information or "fake news" are two different terms. They aver that fake news contains two important variables, which are (I) the information is evidently false and (2) it is shared intentionally to mislead the audience. Meanwhile, they define hoax as "mislead report or misleading but not fully false" (Gunawan and Ratmono, 20I8, 4). In other words, they underline the degree of factuality of the information being shared. To simplify the analysis, this paper puts an emphasis on the intention of people sharing the information. For this purpose, this paper put together fake information, fake news, hoax, and disinformation in the same basket, with the three aforementioned variables being used. The three terms are used interchangeably in this paper.

In Indonesia, hoaxes have been highly distributed through social media. According to an online survey conducted by The Indonesian Information and Telecommunication Society
(Mastel) in 2019 (Mastel.id), about 87.5 percent of the respondents admitted that they received hoaxes mainly from social media (Twitter, Facebook, Instagram), 67 percent of them received hoaxes from chatting applications, and 28.2 percent of them received hoaxes from the websites. The survey also found out that the respondents received hoax in the form of printed text (70.7 percent), old news articles, photos, or video (69.2 percent), and photos with fake captions (66.3 percent). Regarding the topics of the hoax they regularly received, the respondents mentioned that social-political issues (93.2 percent), ethnicity and religion (76.2 percent), government-related topics (61.7 percent), and health (40.7 percent) are the most common topics.

\section{SECURITIZATION AS AN ANALYSIS POINT OF VIEW}

Securitization Theory challenges the established traditional objectivist-realist security that understands the security from a static and state-centric perspective, which mainly situates the military sector as the most pressing security concerns (Sheehan, 2005). In contrast, Securitization Theory, which subscribes to a constructivist paradigm, argues that security is something that is socially constructed. In other words, security is dynamics. Ole Waever (1995, p. 55) argues that "security is not of interest as a sign that refers to something more real: the utterance itself is the act". In other words, by declaring something as a security issue, it can be treated as a security concern, although only if several preconditions are fulfilled. An issue can be securitized if securitizing actors can convince certain audiences that the issue being securitized poses "existential threats" toward certain "referent object". To handle the pressing challenge, "extraordinary measures" need to be implemented as soon as possible (Waever, I995, p. 55; Buzan et al, I998, p.2I). Balzacq (2010) as cited in Neo (2019, p.3) argues that Securitization Theory has six elements, which are (I) securitizing actor; (2) threat; (3) a referent object; (4) audiences; (5) context; and (6) state of exceptionality. 
Securitizing actor is understood as people or speakers of institutions that declare a particular object to be fundamentally threatened. The actors can be anyone, but the elites usually have more chances to be successful in enunciating something as existentially threatened or in other words, to do "speech act" (Buzan et al, I998, p. 36). Besides, a referent object is described as something that is threatened and "has a legitimate claim to survival" (Buzan et al, 1998; Waever 1995). There are two aspects that can determine whether a "speech act" is successful; the internal aspects of speech act (grammar or pattern of the speech act) and the external aspects. The external aspect can be divided into two; (I) the securitizing actors' social capital, and (2) conditions related to the threats (Buzan et al, 2019, p.33).

By using Securitization Theory, one can analyzes the process in which an issue that was not initially considered a security concern can be perceived as a security issue that becomes a priority and more resources are put into it. Buzan et al (I998, p. 23-24) argue that public issues can be "non-politicized, politicized, and securitized". Non-politicized issues shall mean that such issues are not discussed in public spaces, while the politicized issues can be the state's affairs and they are prone to an open public debate. Securitized issues are the issues that are "perceived as an existential threat to particular referent object and an extraordinary measure is offered to handle it (Buzan et al, I998, p.23-24).

The spectrum of public issues can be used to determine where the spectrum of a particular issue is located within a public sphere. The process does not have to be in line with a securitized issue as the final stage. Buzan et al (I998, p. 27), for example, argue that securitization "can be either ad hoc or institutionalized". In other words, an issue that has been successfully securitized can also be "undone" or "desecuritized" into a non-securitized spectrum. One of the reasons for desecuritization is that when the issue is put into a securitized spectrum it will become counterproductive as the handling becomes ineffective (Huysman, I998).
As an example, when the specialized agency in a particular country deems that the spread of novel coronavirus an existential threat to the nation's survival, extraordinary measures will, therefore, be taken; by isolating the entire nation for a year and deploy the entire military personnel to guard the state's border. This discourse is then accepted by the audiences; its citizens and also policymakers, and the extraordinary measures are implemented. However, a few months or years later, a group of civil societies "desecuritized" it by arguing the issue should not be placed in a security spectrum on the first hand because of a variety of reasons, and the audience received it, then the issue can be brought back to non-securitized spectrum. In other words, the "state of exceptionality" (Balzacq, 2010) or "extraordinary measures" (Buzan et al, I998) are brought back to "normal politics". That is because securitization initially occurs due to the combination of "the presence of existential threat" and "to break free of procedures or rules he or she would otherwise be bound by" (Buzan et al, I998, p.25). The existential threat has, therefore, justified "the breaking of the rules".

One of the critiques toward the implementation of securitization studies outside the Western hemisphere is that this theory was initially designed within the political setting of Western and Northern Europe with a relatively mature democratic tradition. Neo (20I9) in his research on the securitization of fake news in Singapore, summarizes this debate, which focuses on the aspect of freedom of expression (Neo, 2019). To justify that securitization theory is applicable in non-western setting, he argues that Singapore, which is to some extent can be considered a "hybrid-regime" still has "models of democratic governance together with the non-democratic institution". (Neo, 2019, p.4).

Indonesia, on the other hand, has been considered a democratic country after the 1998 political reform, although it still faces some challenges. The Economist Intelligence Unit's Democracy Index of 2019 categorizes Indonesia as a "flawed democracy" (The Economist Intelligence Unit, 2020). In addition, several studies on securitization in Indonesia have been 
Graph 3. Spectrum of Public Issue
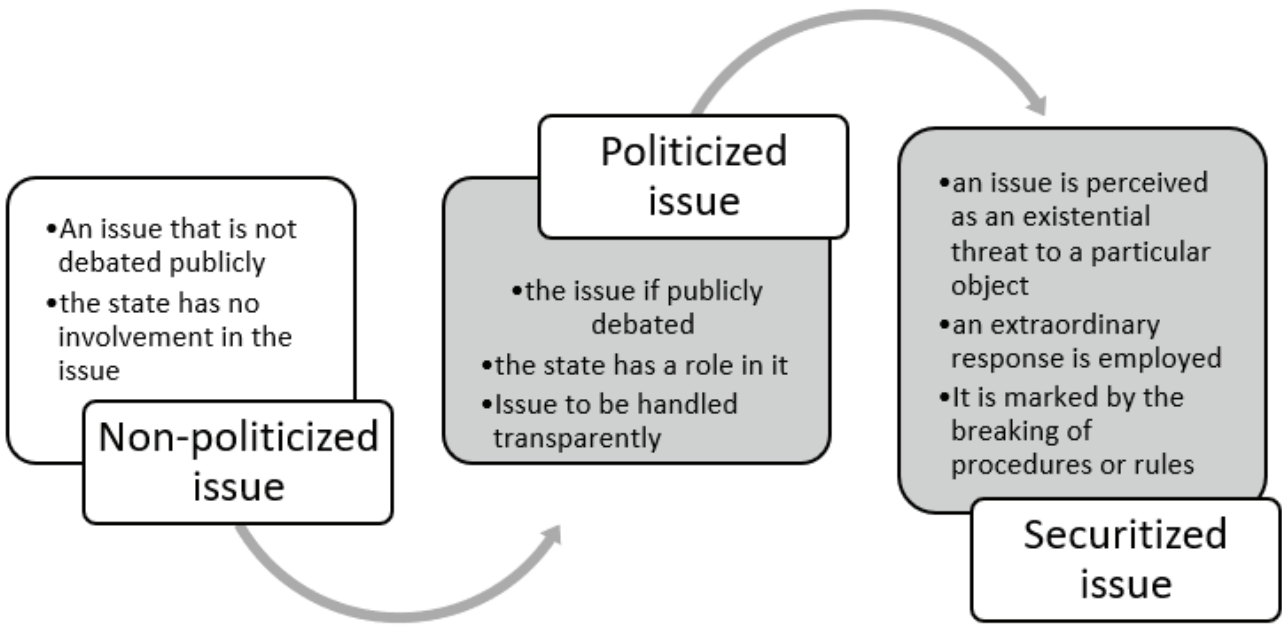

Source: illustrated by author from Buzan et al. (I998: 23-24)

conducted in various field, such as conflict (Kurniawan, 20I8); cybersecurity (Ulum, 20I7); and transit forced migrants (Lee, 20I7). Those studies show that Securitization Theory is applicable in Indonesian democratic context. Kurniawan (2018) argues the securitization dynamics in Indonesian early democratic transitions was in line with Indonesian democratization objectives. Lee (2017) on the other hand, does not discuss the nexus of democracy and securitization, but implicitly touch upon it when explaining the possible reason behind the actors' motives to securitize transit forced migrants. Among several explanations, he mentions securitization "serve to maintain legitimacy by showing to the public that the government conducted harsh policies to deal with the aliens" (Lee, 20I7, p. 96). The allegedly "performative action" conducted by the government in public spheres to convince citizens is part government accountability to the public, which is part of democratic values.

\section{SECURITIZATION DYNAMICS}

Referring to the securitizing moves that happened from 2017 to 2019 , this section tries to analyse the issues by means of internal and the external aspects of "speech act" (Buzan et al, I998). One of the external factors is the increasing cases of hoax and disinformation distributions, which serves as a facilitating condition. It has enabled the utterance of hoaxes as existential threats to be in line with the audiences' mood or "the public mood" (Ringmar, 2018). Meanwhile, the discussion on the internal factors is divided into two subsections, namely the triumvirates of actors; threats and audiences; as well as the existential threats executed. In addition to that, this section briefly discusses possible desecuritization.

\section{Hoaxes on the Rise: A Facilitating Condition}

During the time when public awareness on hoaxes and disinformation emerged exponentially between 2017 and 2019 when Indonesia held an Election in April (see Graph I and 2), the reported cases on hoaxes and disinformation distribution had also increased. Data from the Indonesian Ministry of Communication and Information or Kominfo, a specialized agency which also supervises the internet, shows that from August 2018 to February 2019, two months before the election day, there were increasing trends of hoaxes reported and found by the ministry per month. In August 2018, there were 25 contents, September 2018 (27), October (53), November (63), December (75), while January 2019 and February 2019, I75 contents and 353 contents respectively. During those seven months, Kominfo handled 77I hoax or fake information, of which mainly related to 
political issues (I8I contents), health issues (I26 contents), and governmental issues (II9 contents), as well as hoaxes directed towards individuals that reached IIo contents (Kominfo. go.id, 13/3/2019).

The trend can serve as facilitating condition for securitization. The position of the enunciator of the threat and the conditions related to the threat being enunciated are the two decisive factors to convince the audience. It is important to bear in mind that, this study, like other securitization theory studies, does not intend to analyse the "actual" or the "real" security threat (Buzan et al, I998, p.35). This study does not focus on whether hoaxes and disinformation distribution have become an "actual" threat to Indonesia. This study therefore argues that the increasing cases of hoaxes can facilitate the audience to accept the securitizing moves. The spread of hoaxes can arguably influence "public mood". Ringmar (2017, p.460), argues that "a public mood is the mood which is shared by people who attend the same public performance". The public, according to Ringmar, means an audience, which is a group that pays "attention to the same thing" (Ringmar, 20I7, p.460). In this case, the same thing that the audiences share is the hoax and disinformation distributions.

During the period of 20I7-20I9, several viral hoaxes gained public attentions and became online discussion. Based on Turnbackhoax.id, a database of hoaxes made by the Indonesian Anti-Slander Society (Mafindo), it is most likely that hoaxes and disinformation related to the 2019 Elections can be divided into six categories; (I) hoaxes slandering the two presidential candidates; Joko Widodo and Prabowo Subianto; (2) hoaxes delegitimating the electoral processes; (3) hoaxes related to China; (4) hoaxes related to religious-based politics; (5) hoaxes related to communism; (6) hoaxes related to the combined issues mentioned above.

One example of the hoax that is a combination of several categories was distributed online through Facebook and was subsequently reported to Mafindo on February 22, 2019. The hoax provided false information saying that there were Chinese citizens who came to the Indonesian Election Commission to have their names recorded into the voter's registration database. It was, according to the sender of hoax, the real evidence that tens of millions of "ghosts voters list" was prepared to accommodate the Chinese migrant workers who have fake Indonesian identity cards (Turnbackhoax.id, 22/02/2019). The hoax about China's interference on the election and Chinese workers coming to Indonesia has regularly arisen within different framing. That is because the narratives allegedly correspond well with some of the people's prejudice. Before the 1998 Indonesian reform, the Indonesian Chinese descendants faced discrimination under the New Order regime for around 30 years. The root of social discontent toward Indonesian Chinese descendants partially due to socio-economic gap between the Chinese descendants and other ethnic groups in the country. There have been several anti-Chinese violence cases in Indonesia since the country's independence in 1945 (Purdey, 2006).

Another example of a hoax that was distributed widely through Whatsapp is that there were seven containers from China at Jakarta's port with millions of presidential elections' casted ballots for the benefit of the incumbent presidential candidate (Turnbackhoax.id, 03/0I/20I9). The Indonesian Elections Commission then reported the case to the Indonesian National Police. The information was confirmed as fake because all of the productions of the election ballots were handled by local companies in Indonesia. Besides, when the hoax became a hot issue in early January 2019, the ballot papers had not been printed yet (Kompas, 04/o1/2019).

Many more hoaxes were targeted at the incumbent, Joko Widodo and also his rival, Prabowo Subianto. Jokowi, for example, was falsely slandered to be a person whose birth name was Herbertus, a Christian as well as a Chinese descendant, who changed his name into Joko Widodo before he was nominated a candidate for mayor of Solo, Central Java. His father was wrongly accused to be an activist of the prohibited communist organization. This slander emerged during the 2014 Presidential 
Election but re-emerged before the 2019 Election. Jokowi had clarified this falsehood several times on different occasions (Turnbackhoax.id, I4/Io/20I7). Hoaxes related partly to Prabowo was distributed through Whatsapp and was reported to Mafindo on April I8, 20I9, a day after the election. The false information urged people not to go anywhere because there would be a huge demonstration to reject the election results. The fake information claimed that several members of the Indonesian special forces in the military that are loyal to Prabowo provoked masses, and therefore the Chief of the Indonesian National Police had ordered to shoot the rioter (Turnbackhoax.id, I8/04/2019).

Since hoax distribution in Indonesian online public spheres has influenced the public moods and thus provides a fertile ground for the audiences' acceptance toward online disinformation securitization, there was also a convincing evidence that international and regional influence played a role. The 2016 US Presidential Elections and how narratives of hoaxes and disinformation have influenced the behaviours of US voters and subsequently determined the election result were also the hot issues among Indonesian public spheres in early 20I7. At the regional level, there were relatively similar "mood" toward hoax and disinformation. Association of Southeast Asian Nation (ASEAN) in mid-2018, announced a "Declaration of Framework to Minimise the Harmful Effects of Fake News" (Neo, 20I9, p.2).

\section{The Triumvirates: Actors, Threats, and Au- diences}

In a democratic and open public sphere, every person can be a securitizing actor. However, for the audiences to accept the securitization narratives, the actors should be those people who hold authority or people who are perceived by the audiences as trustworthy. According to Buzan et al (I998), politicians, bureaucracies, and pressure groups are common securitizing actors. In the case of securitization of hoax in Indonesia, the actors who represented hoaxes as existential threat range from high ranking government officials, specialized agencies, as well as public figures. The Indonesian President
Joko Widodo; the Head of House Representative Bambang Soesatyo; the Indonesian Military Commander Air Chief Marshal Hadi Tjahjanto; the Coordinating Minister for Political, Law, and Security Affairs Wiranto; and the Minister of Communication and Information Rudiantara, are among government officials who represented hoaxes as security threats, within the analyzed news samples.

The discourse analyses on the print and online news articles concerning hoax, fake information, and disinformation in Indonesia during 20I7-20I9, show that there are two types of securitization narratives appeared in public spheres, namely (I) representing hoaxes as threat toward Indonesian unity; and (2) associating hoax with other kinds of security threats.

The narrative suggesting that the nation is under threat of disintegration has appeared regularly in the media. In a public seminar that is also reported in the website of the Indonesian House of Representatives (HoR), the House Speaker, Bambang Soesatyo, states that hoaxes and hate speeches are a terror toward democracy. "Distributing hoax means to fire up hatred and open the case for the nation's disintegration," says Bambang Soesatyo ( $d p r$. go.id, 28/3/20I9). Disintegration, as opposes to a condition of unity, has alarmed the Indonesians who witnessed or know several cases of disintegrations in the pasts. In addition, during the 20I9 Elections, narratives of the urgent need for all share-holders to maintain unity in the time of heated political polarization, appeared regularly in the media.

The Indonesian President, Joko Widodo, when talking about hoaxes and slander in a political event also highlights the importance of maintaining unity and social harmony because those are the biggest assets for Indonesians (Detik.com, 20/10/2018). On another occasion, President Joko Widodo also underlines the danger of hoax for the national unity and the sense of brotherhood among Indonesians. He orders the Chief of Indonesian National Police to conduct thorough investigations against cases of hoaxes and hate speeches. "It can 
disintegrate our nation. If hoax continues to spread, (it can lead to the nation being) torn apart," said Joko Widodo (Kompas, 7/3/2018).

A hoax that is assumed as a pressing challenge for the unity of Indonesia can revoke a negative image of what happened in the pasts; separatist and rebellions, racially motivated riots, and religious-driven riots. This is due to the fact that Indonesia was established from a shared "imagination" of different elements of the nation, based on shared historical similarity and a similar aspiration for the future, which then formed "an imagined community" (Anderson, I983). This "imagination" binds together different independent regions, ethnics, and kingdoms that were in existence long before Indonesia as a nation was established. That is why a threat to Indonesian unity can be seen by Indonesian elites or societies in general as an existential threat to the nation. Historian RE Elson argues that Indonesian leaders have always insisted that "Indonesian unity is eternal, should and cannot be challenged, and should be inherited" (Elson, 2008, p.478). In that sense, assuming that hoax is a threat to the nation's unity leads to a sense of emergency.

Another securitizing narrative resulting from the news analyses is that securitizing actors associate hoaxes with dangerous traditional security threats, such as terrorism and radicalism. The Minister of Home Affairs Tjahjo Kumolo in a national meeting with high-ranking local government officials argued that the threat to the unity of Indonesia is not only posed by the military force but also other forces, such as radicalism, terrorism, intolerance, hoax, and cyberwar. (Kompas, I8/10/2018). Similarly, the Indonesian Coordinating Minister for Political, Law, and Security Affairs Wiranto, during a press conference after a meeting discussing the 2019 Election's security preparation, connected hoaxes with terrorism. "When people are threatened with hoaxes, to prevent them from going to the polling stations, that is considered a threat and the act of terror. For that reason, we will enforce Terrorism Law," says Wiranto as quoted in CNNIndonesia.com (20/03/2019). Soon after, the statement gained support and critique from different public figures. Terrorism is considered as extraordinary security issue for Indonesia that had witnessed several terrorist attacks within the country. However, the statement to enforce Terrorism Law was not executed within the election's time-span.

The Indonesian Military Commander, Air Chief Marshal Hadi Tjahjanto used militaryparallel terms when he discussed hoax with several mass media editors in 2018. "Hoax has recently been widespread and has become a threat to the societies. This power (hoax) is very tremendous, even more destructive than nuclear weapon," said Hadi Tjahjanto (Kompas, 24/7/2018). By associating hoax with the deadly nuclear weapon, the military commander stressed on the horror a hoax may bring. In a different context, Huysman, when discussing securitization of migration in Europe, used a concept named "security continuum", stating that "the security connotation of terrorism, drug trafficking, and money-laundering may be applicable in migration issues" (Huysman, 2000, p.760; Huysman, 2006, p.7I). To some extent, the "security continuum" can also be used to understand rhetoric made by the securitizing actors in Indonesia who associate hoax with terrorism, radicalism, and also military threat. All of those narratives can be useful to convince audiences to accept that hoax is ultimately dangerous for the nation.

Table 2. Public Opinion Polling What worries you the most about the impact of hoaxes in social media?

\begin{tabular}{ll}
\hline Responses & Percentage \\
\hline $\begin{array}{l}\text { It becomes harder to find truth from } \\
\text { information }\end{array}$ & 16.4 \\
\hline $\begin{array}{l}\text { It can trigger conflicts among mem- } \\
\text { bers of societies }\end{array}$ & 19.6 \\
\hline $\begin{array}{l}\text { It can lead to the nation and state's } \\
\text { disintegration }\end{array}$ & 60.2 \\
\hline Nothing & 0.6 \\
\hline Did not know/did not answer & 3.2 \\
\hline Total & 100 \\
\hline
\end{tabular}

Source: Kompas Newspaper, Research and Development Department (2019)

The narratives of hoax as a threat are accepted by the audiences at the elite's level as well as at the grassroots level, which is reflected 
on various surveys and opinion polling. For example, an opinion polling conducted by Kompas Newspaper's Research and Development Department on November 6-7, 2019, involving 520 respondents from 17 big cities in Indonesia, shows that 60.2 percent of respondents are worried that hoax in social media can lead to the nation and state disintegration. In addition, the news articles analyzed in this case study also shows a variety of actors talking about the danger of hoax. It not only comes from government officials but also from civil society actors and religious leaders. The survey shows that audiences relatively support the securitizing narrative that hoaxes can ruin Indonesian unity.

\section{EXTRAORDINARY MEASURES: THROTTLING AND SHUTDOWN OF THE INTERNET}

Buzan et al (1998, p.23-24) highlight that securitization is successful with the presence of two conditions: (I) something is accepted by the audiences as an existential threat to a particular object; (2) an extraordinary or exceptional solution to handle it is accepted. The first condition has been discussed in the previous section. Extraordinary measures were not openly publicized by the securitizing actors in their narratives, but such measures were implemented later on, at least on two occasions by a specialized agency in Indonesia, namely the Ministry of Communication and Information (Kominfo). The first occasion was when the government conducted a nationwide internet throttling on May 22-23, 2019. The second occasion was when the government throttled internet in Papua and West Papua Provinces on August 19-20, 2019, which was then followed by internet shutdown from August 2I to September 4, 2019 .

The nationwide internet throttling was initiated after the 2019 Indonesian Election, when the Indonesian Elections Commission announced the official vote-recapitulation results at national level for both legislatives and presidential elections on May 2I, 20I9. The incumbent candidate, Joko Widodo and his vice-presidential candidate, Ma'ruf Amin won more votes than their rival, Prabowo Subianto and his vice president candidate Sandiaga Uno. Prabowo-Sandiaga's team refused to accept the result. In the same day, thousands of protesters gathered in front of the Election Supervisory Agency (Bawaslu), to refuse the official result. In the evening of May 2I, a riot erupted in front of the Bawaslu office. Around 700 people were injured, and eight people were killed (thejakartapost.com, 23/05/2019).

Kominfo started to throttle the internet in the afternoon of 22 May 20I9. That was the first time Indonesia imposed this kind of restrictions on social media access within an emergency situation (thejakartapost.com, 29/10/2019). In its press release Number Io6/ $\mathrm{HM} / \mathrm{KOMINFO} / 05 / 2019$, the Minister of Communication and Information Rudiantara stated that the government temporarily and gradually throttled the access to several social media and instant messaging platforms. He argued that the measure was taken to limit the distribution of hoaxes related to the peaceful protest concerning the announcement of the 2019 Election results. The internet features whose access was limited were pictures, photos, and videos distributed through Facebook, Instagram, and Twitter, as well as Whatsapp. The minister believed that the policy was legally justified and it was necessary because the government had no capabilities to take down hoaxes one by one. "Because there are more than 200 million smartphone users in our country". And almost all of them use Whatsapp," said Rudiantara in the press release (kominfo.go.id, 22/05/2019).

The second episode of internet throttling happened within different socio-political settings. On August 19-20, 2019, the Ministry of Communication and Information slowed down the internet speed in Papua and West Papua Provinces to tackle the dissemination of hoaxes and disinformation that could escalate the unrest in the provinces (Kompas, 23/08/2019). The unrest which was subsequently followed by riots that killed several people was allegedly triggered by a racial discrimination case in Surabaya, East Java targeting several Papuan students a few days earlier. The retaliation mass movements were seen in several cities in Papua and West 
Papua. Two days after the internet throttling, the Indonesian government completely shut down the internet in Papua and West Papua on 2I August.

This is also recorded in history as the first internet shutdown by the Indonesian government (Kompas, 26/08/20I9). The Ministry of Communication and Information on its press release Number I55/HM/KOMINFO/o8/20I9 stated that the telecommunication data services were blocked in order "to accelerate the recovery of security and social order in Papua and its surrounding areas. The decision was made after consultation with law enforcers and related institutions." (Kominfo.go.id, 21/08/2019). Minister of Communication and Information Rudiantara insisted that the decision was legal and was made to protect the people. He said that if the government did not restrict the internet services in Papua, the government would be considered to have failed to protect Indonesian people as a whole, not just Papuans. He further argued that the President himself ordered him to restrict the internet there (Detik.com, 24/08/2019).

Internet throttling and internet shutdown are not common ways of dealing with protests, riots, hoaxes and disinformation in Indonesia. Therefore, it can be argued that the two cases of internet restriction were an extraordinary measure conducted by the securitizing actors, even when it was not openly mentioned when they talked about the existential threats posed by hoaxes. Beforehand, hoaxes were handled by taking down the contents or blocking the website that published false information (verse 40 of Law Number II/20I6 about Electronic Information and Transaction). The Ministry of Communication and Information, in preparation to deal with the political event of the 20I9 Election, formed a special team including social media platform representatives with the main task "to block negative contents, such as hoax and pornography" (Azali, 20I7, p.9). Besides, hoax producers and distributors would face criminal investigation conducted by the Indonesian National Police (Setiawan, 2019).
Internet throttling or shutdown has been widely debated among the two polarized groups: the "free speech" group and "national interest" or "national security" group (Kulesza, 20I4). Freedom of expression is very central in order for a democratic system to function well. This is acknowledged as basic human rights within the Universal Declaration of Human Rights (UN, I948). In details, this right is also guaranteed in the International Covenant on Civil and Political Rights (I976). It is stipulated in Article 49, paragraph 2, of the covenant that "everyone shall have the right to freedom of expression; this right shall include freedom to seek, receive, and impart information and ideas of all kinds, regardless of frontiers, either orally, in writing or print, in the form of art, or through any other media of his choice". However, there are also several limitations to that right as stipulated in paragraph 3, stating that "but these shall only be such as, provided by law and are necessary; (a) for respect of the rights or reputations of others; (b) for the protection of national security or of the public order, or of the public health or morals". (ICCPR, I976).

In that sense, internet throttling and shutdown can be seen as an unusual way of dealing with disinformation because of their emergency nature which is used as the basis for neutralizing the threat to the nation's unity. In the future, it might be possible that the Indonesian government will implement the same policy when facing the same threats. The new Minister of Communication and Information Johnny G Plate, argues that similar restrictions of social media can be imposed again in the future in the time of "emergency". "The constitution grants freedom of speech. The restriction will be imposed when necessary. Our purpose is to limit negativity," says Johnny as being quoted in Thejakartapost.com (29/10/2020).

Having said that, when the Indonesian government took extraordinary measures by throttling the internet in May 2019 to prevent a riot from worsening and subsequent temporary shutdown the internet in Papua and West Papua in August 2019, it is argued that the securitization of disinformation is completed. In this case, not only the securitizing move is accepted by 
the public, but the government also executed the measures. Different scholars highlight a different element of securitization to mark the success of a securitizing move. Buzan et al (1998, p. 33) underlines "successful securitization is not decided by the securitizer but by the audience of the security speech act". In other words, when the audiences accept the securitizing moves, then the securitization is successful. However, other scholars argue it is the implementation of extraordinary measures that mark the success of securitization, not solely when the securitization narrative is accepted by the audiences (Kurniawan, 2018). Besides, Huysmans (2000, p. 75I), argues securitization can also be imposed by "restrictive policy and policing", not only through "speech act". In that sense, Huysmans also highlights the importance of the non-discursive aspect of securitization, which is an extraordinary measure's execution.

In the case of securitization of online hoax in Indonesia, it is the implementation of extraordinary measures - internet throttling and internet shutdown - that make the securitizing moves completed. Public acceptance on the danger of online hoax to the Indonesian unity serves as a transition that develop a certain "public mood" (Ringmar, 20I7; 460) that, consequently, pave the way toward the implementation of extraordinary measures. This is because, within the securitizing actors' narratives, the extraordinary measures are absent. There were no mention of internet shutdown or internet throttling in securitizing statements produced by the elites.

\section{DESECURITIZING MOVES}

This empirical study has shown that Securitization Theory is applicable in the Indonesian democratic context. With all of its weaknesses, Indonesian democracy has vibrant public spheres, where people or actors with different interests still can debate public policies. For the study of securitization theory, this is essential. According to Buzan et al. (I998, p.28), in democracy, why some issues is handled through extraordinary measures and perceived as security issues, "must be argued in public spheres". This empirical study therefore shows
Securitization Theory can be implemented in non-Western settings when democratic public spheres exist.

In one hand, democracy is an elemental aspect for the applicability of Securitization Theory, on the other hand, the securitization process can also shape the course of democracy. Buzan et al. (I998, p.28) warns that securitization should not be idealized since "it works to silence opposition and has given power holders many opportunities to exploit threats for domestic purposes, to claim a right to handle something with less democratic control and constrain". In the case of online hoax in this study, after the specialized agency implemented internet throttling and internet shutdown to control hoaxes and disinformation on two different occasions, a group of civil societies, in January 2020 , sued the Indonesian government for its policy to throttle and shutdown the internet in Papua and West Papua.

Until mid-February 2020, the judicial process is still ongoing. In their press release to the media, the group, self-proclaimed as Team of Press Freedom Defender, states that "this lawsuit can be a lesson-learned so as to prevent future internet bandwidth throttling by the government while battling hoaxes." (lbhpers.org, 22/OI/2020). They underline the negative impact of internet throttling and internet shutdown toward the freedom of accessing information, which is essential for a democracy to function well. This writing does not intend to explore the impact of securitizing online hoax toward Indonesia democracy. However, the plausibility of online securitization has negative effect toward democracy is something that could also be considered. Especially, when scholars have warned that Indonesian democracy has been stagnant for a decade (e.g Mietzner, 20I2). However, one also has to bear in mind that it does not mean that securitization is something bad since; "desecuritization is preferable in the abstract, but concrete situations might call for securitization" (Waever, 20II, p. 469).

The desecuritizing move in the judicial corridor, as well as in public discourse, aims to bring back the handling of online hoaxes 
from an emergency situation to the realm of a normal politics. Based on his study on securitization in Indonesian early democratic transition, Kurniawan (2018, p.208) underlines that the decision-making process in security sectors can "reflect the domestic power struggle between the competing actors". This finding can also be understood in both, the securitization and desecuritization dynamics. However, it is still too early to analyze the effectiveness of desecuritization initiated by civil society since there are still unknown elements of the desecuritizing moves. Immediate questions will be revolving around can non-governmental actors be successful in desecuritizing the issue? How will the securitizing actors respond to the desecuritizing moves? Who are the targeted audiences? and What kind of normal political measures the desecuritizing actors offer? Only through further research one can shed some light on these questions.

\section{CONCLUSION}

This study argues that online hoaxes, disinformation, and fake information have been securitized by political elites from 2017 to 2019 . In other words, the elites perceive them as a threat to national unity. However, this study is not intended to measure whether hoaxes and disinformation bring an actual threat to the nation. Instead, this paper analyses the process of shifting online hoaxes from non-securitized issues into securitized ones. An issue can be securitized if securitizing actors can convince certain audiences that the issue to be securitized poses "existential threats" toward certain "referent object", therefore to handle the pressing challenge, "extraordinary measures" need to be implemented as soon as possible (Waever 1995 , p. 55; Buzan et al., I998, p. 2I).

The securitization process occurred in response to the increasing trends of hoaxes distribution on the internet through social media, website, or instant messaging platforms when Indonesia was preparing for the highly contested 2019 Elections. This phenomenon serves as a facilitating condition of the successful securitization. Moreover, this study finds that hoaxes are represented as a threat to Indonesian unity that may as well lead to social unrest and something that the audiences fear to recur: disintegration. Besides, hoaxes are also associated with other threats, such as terrorism and radicalism. The securitization process was completed when the Indonesian government took extraordinary measures by throttling the internet in May 2org to prevent a riot from worsening and subsequent temporary internet shutdown in Papua and West Papua in August 2019. Therefore, this empirical study has shown that Securitization Theory is applicable in non-Western setting, such as in Indonesian democratic context.

Desecuritizing moves have recently emerged from several civil societies but the impacts are yet to be known. It might be interesting to further analyze whether the securitization of online hoaxes is institutionalized as well as what side-effects the securitization process brings to the Indonesian democracy. That is something this study still unable to explains. Furthermore, this study provides a helicopter analysis of a securitization process of moving hoax toward a securitized issue. However, it does not provide telescopic analysis on the power struggle between the securitizing actors as well as whether the targeted audiences were public as a whole, or only governmental elites that have authority to execute the extraordinary measures. To explain this, a different method and research question are needed.

\section{REFERENCES}

Anderson, B. (I99I). Imagined Communities: Reflections on the Origin and Spread of Nationalism. London: Verso.

APPJI. (2018). Hasil Survei Penetrasi dan Perilaku Pengguna Internet Indonesia 2018 [the 2018 Survey of Internet Penetration and Internet Users in Indonesia]. Available in https://www. apjii.or.id/content/read/39/4Io/Hasil-SurveiPenetrasi-dan-Perilaku-Pengguna-InternetIndonesia-2018 (Accessed February 15, 2020).

Azali, K. (20I7). "Fake News and Increased Persecution in Indonesia”. In Perspective, issue 20I7, No. 6r. Available in https://iseas.edu.sg/ images/pdf/ISEAS_Perspective_20I7_6I.pdf (Accessed Januari 3I, 2020). 
Bute, S. (20I4). "The Role of Social Media in Mobilizing People for Riots and Revolutions: Four Case Studies in India”. In Patrut, Bogdan and Patrut, Monica (Eds), Social Media in Politics: Case Studies on the Political Power of Social Media. New York: Springer.

Buzan, B. Waever, O. \& De-Wilde, J. (I998). Security: A New Framework of Analysis. Boulder CO: Lynne Rienner.

Dolinec, V. (2010). The Role of Mass Media in the Securitization Process of International Terrorism. Politické vedy, I3(2), 8-32.

Elson, R. (200I). Suharto: A Political Biography. Cambridge: Cambridge University Press.

Fetzer, J. (2004). "Disinformation: The Use of False Information". In Minds and Machines Vol I4, p. 23I-240.

Gazali, E. (20I4). "Learning by Clicking: An Experiment with Social Media Democracy in Indonesia”. In the International Communication Gazette Vol. 76 (4-5): pp 425-439.

Gunawan, B. \& Ratmono, B. (2018). Kebohongan di Dunia Maya: Memahami Teori dan Praktikpraktiknya di Indonesia [Lies in Cyberspace: Understanding the Theory and Its Practices in Indonesia]. Jakarta: Kepustakaan Populer Gramedia.

Gupta, R. \& Brooks, H. (2013). Using Social Media for Global Security. Indiana: John Wiley\&Sons, Inc.

Huysmans, J. (2000). "The European Union and the Securitization of Migration". JCMS: Journal of Common Market Studies, vol. 38, no. 5, pp. 75I-777.

Huysmans, J. (2006). The Politics of Insecurity: Fear, Migration, and Asylum in the EU. Abingdon: Routledge.

Ireton, C. \& Posetti J. (2018). Journalism, 'Fake News'\& Disinformation. Paris: United Nations Educational, Scientific and Cultural Organization. Available in https://en.unesco.org/sites/ default/files/journalism_fake_news_disinformation_print_friendly_o_o.pdf(Accessed February I2, 2020).

Kulesza, J. (2014). "Social Media Censorship vs State Responsibility for Human Rights Violations". In Patrut, Bogdan and Patrut, Monica (Eds), Social Media in Politics: Case Studies on the Political Power of Social Media. New York: Springer.

Kurniawan, Y. (2018). The politics of securitization in democratic Indonesia. Springer International Publishing.
Lee, A. (2016). "Pasang Surut Partisipati Politik di Dunia Maya [The Tides of Political Engagement on Cyber Spaces]". In Tinjauan Kompas: Menatap Indonesia 2016 [Kompas Outlook: Indonesias Outlook 20I6]. Jakarta: Penerbit Buku Kompas

Lee, A. (20I7). "Forced Migrants, Media, and Securitization: Making Sense of the Changing Representations of Transit Asylum Seekers in Indonesian Print Media”. Journal of ASEAN Studies, 5(2), pp.75-Ior.

Lee, A. (2018). "Guarding the Elections Online": New Practices, Trust, and Empowerment of Citizens Identities. Journal of Indonesian Social Sciences and Humanities, 8(I), II-28.

Lim, M. (20I3). "Many Clicks but Little Sticks: Social Media Activism in Indonesia". In Journal of Contemporary Asia Vol. 43, No. 4: pp 636-657.

Lim, M. (20I7). Freedom to Hate: Social Media, Algorithmic Enclaves, and the Rise of Tribal Nationalism in Indonesia. Critical Asian Studies, 49(3), 4II-427.

Mastel. (2019). Hasil Survei Wabah Hoax Nasional 2019 [The Survei Result of National Hoax Plague 20I9]. Available in https://mastel.id/hasilsurvey-wabah-hoax-nasional-2org/(Accessed in February 22, 2020).

Nash, V. (2013). "Analyzing Freedom of Expression Online: Theoretical, Empirical, and Normative Contributions". In Dutton, William H (Ed). The Oxford Handbook of Internet Studies. Oxford; Oxford University Press.

Neo, R. (2019). "The securitisation of fake news in Singapore”. In International Politics. https:// doi.org/Io.I057/s4I3II-0I9-00I98-4

Nugroho A. 2019. "Comparative Study of Hoax Handling Policies in Indonesia and Singapore”. Proceedings of the First International Conference on Administration Science (ICAS 20I9). https://doi.org/Io.299I/icas-I9.20I9.74

Priyono, A.E, Hamid, U., Ariane, Z., \& Obrigadoz. W. (20I4). Media Sosial Alat Gerakan Sipil: Belajar dari Suksesi Jakarta dan Masa Depan Indonesia. Jakarta: Public Virtue Institute.

Purdey, J. (2006). Anti-Chinese Violence in Indonesia, I996-I999. Singapore: Singapore University Press.

Ringmar, E. (2018). What are public moods?. In European Journal of Social Theory, 2I(4), pp.453-469. 
Salma. A. (2019). Defining Digital Literacy in the Age of Computational Propaganda and Hate Spin Politics. In The Ioth IGSSCI (International Graduate Students and Scholars' Conference in Indonesia) News Media and the Changing Social Landscape of Cintemporary Societies: How are New Media Reshaping the Whole Aspects of Life of Contemporary Societies? KnE Social Sciences, pp 323-338. doi: I0.I8502/kss.v3i20.4945

Setiawan, A. (2019). "Analisis Yuridis terhadap Berita Bohong (Hoax) yang Beredar di Media Sosial Berdasar Hukum Positif" [Juridical Analysis Fake News (Hoax) in Social Media Based on Positive Law]". In Dinamika, Vol 25, No 6, pp. 27-34. Available in http://www.riset.unisma. ac.id/index.php/jdh/article/view/3I7I.

Sheehan, M. (2005). International Security: An Analytical Survey. Colorado: Lynne Rienner Publishers.

Siaran Pers [Press Release] No. I55/HM/KOMINFO/o8/2019: Pemblokiran Layanan Data di Papua dan Papua Barat [Data Services Blocking in Papua and West Papua]. Kominfo.go.id 2I/8/20I9. Available in https://www.kominfo. go.id/content/detail/2082I/siaran-pers-noI55hmkominfoo820I9-tentang-pemblokiranlayanan-data-di-papua-dan-papua-barat/o/ siaran_pers (Accessed February 5, 2020).

Siaran Pers [Press Release] No. 5I/HM/KOMINFO/20I9: 77I Hoaks Berhasil Diidentifikasi Kemkominfo Sejak Agustus 20I8 Hingga Februari 2019 [77I Hoaxes Identified by Kemkominfo since August 2018 until February 2019]. Kominfo.go.id. 13/3/2019. Available in https://kominfo.go.id/content/detail/I6924/ siaran-pers-no-5Ihmkominfoo320I9tentang-77I-hoaks-berhasil-diidentifikasikemkominfo-sejak-agustus-2018-hinggafebruari-2or9/o/siaran_pers (Accessed February 4, 2020).

Siaran Pers [Press Release] No.Io6/HM/KOMINFO/05/2019: Pembatasan Sebagian Fitur Platform Media Sosial dan Pesan Instan [Partial Throttling of Social Media and Instant Messaging Features]. Kominfo.go.id, 22/5/20i9. Available in https://kominfo. go.id/content/detail/I8868/siaran-pers-noIo6hmkominfoo520I9-tentang-pembatasansebagian-fitur-platform-media-sosial-danpesan-instan/o/siaran_pers (Accessed February 5, 2020).
Siaran Pers [Press Release]: President Jokowi Absent in the Preliminary Session of the Trial on Internet Shutdown Lawsuit. Lbhpers.org, 22/oI/2020. Available in http://lbhpers.org/ presiden-jokowi-mangkir-di-persidanganperdana-gugatan-internet-shutdown/ (Accessed 26 February 2020).

Surbakti, R. (20I7). "Pemilu Terbesar di Dunia [The Biggest Election in the World]. In Kompas, May 3, p.6.

Suriadi, A. (2018). "The Language of Hoax: Explosive Growth of Fake News in the Biggest Muslim Society". Proceedings of the 2nd Internasional Conference on Culture and Language in Southeast Asia (ICCLAS 20I8). Available in https://www.atlantis-press.com/proceedings/ icclas-I8/559I30I5. (Accessed January 3I, 2020).

Tapsell, R. (20I7). Media Power in Indonesia: Oligarchs, Citizens and The Digital Revolution. London: Rowman \& Littlefield International Ltd.

The Economist Intelligence Unit. (20I9). Democracy Index 20I9. Available in https://www.eiu.com/ public/topical_report.aspx?campaignid=de mocracyindex2019 (Accessed February 24, 2020).

Ulum, M. (20I7). "Cyber Culture and Cyber Security Policy of Indonesia: Combining Cyber Security Civic Discourse, Tenets, and Copenhagen's Securitization Theory Analysis. In Proceeding the Ist International Conference on Social Sciences University of Muhammadiyah Jakarta, Indonesia, I-2 November 2017

Utami, P. (2018). "Hoax in Modern Politics: The Meaning of Hoax in Indonesian Politics and Democracy". In Jurnal Ilmu Sosial dan Ilmu Politik, Vol 22, Issue 2, p. 85-97

Waever, O. (I995). "Securitization and Desecuritization”. In Lipschutz, R.D. (Ed). On Security. New York: Columbia University Press

Waever, O. (20II). "Politics, Security, Theory". In Security Dialogue, Vol 42 (4-5), p. 465-48o.

Yanti, M. \& Yusnaini. (2018). "The Narration of Digital Literacy Movement in Indonesia". In Informasi: Kajian Ilmu Komunikasi, Vol. 48, No 2, p 243-255. https://doi.org/I0.21831/ informasi.v48i2.2II48

International Covenant on Civil and Political Rights. (I976). Available in https://www.ohchr.org/ Documents/Professionallnterest/ccpr.pdf

Universal Declaration of Human Rights. (I948). Available in https://www.un.org/en/udhrbook/pdf/udhr_booklet_en_web.pdf 
Undang-Undang Nomor II Tahun 2008 tentang Informasi dan Transaksi Elektronik [Electronic Information and Transaction Law]. Available in https://jdih.kominfo.go.id/ produk_hukum/view/id/I67/t/undangunda ng+nomor+II+tahun+20o8+tanggal+2I+apr il++2008 (Accessed January 20, 2020)

Undang-Undang Nomor i9 Tahun 2016 tentang Perubahan Kedua Atas Undang-Undang Nomor II Tahun 2008 tentang Informasi dan Transaksi Elektronik [Electronic Information and Transaction Law]. Available in https:// jdih.kominfo.go.id/produk_hukum/view/ $\mathrm{id} / 555 /$ t/undangundang+nomor+I9+tahun+ 20I6+tanggal+25+november+20I6 (Accessed January 20, 2020)

\section{News Articles and Online Reports}

"Blokir Data Internet di Papua, Rudiantara: Ada Dasar Hukumnya [Internet Shutdown in Papua, Rudiantara: The Legal Basis is Ezisted] ", (20I9), Detik.com, $24^{\text {th }}$ August. Available in https://news.detik.com/berita/d-4679470/ blokir-data-internet-di-papua-rudiantaraada-dasar-hukumnya (Accessed February 3, 2020)

"Daerah Butuh Internalisasi Nilai Pancasila [Regions Needs the Internalization of Pancasila's Value]", (2018), Kompas, I8 ${ }^{\text {th }}$ October, p.3.

"False News Spread on Social Media Incited Riot in N Sumatera: Police Chief", (2016), Thejakartapost.com, $3 \mathrm{I}^{\text {st }}$ July. Available in https://www. thejakartapost.com/news/2016/07/31/ false-news-spread-on-social-mediaincited-riot-in-n-sumatra-police-chief.html (Accessed January 24, 2020)

"[Fitnah] Jokowi Nama Lahirnya Herbertus [Slander, Jokowi's Birth Name is Herbertus]", (20I7), Turnbackhoax.id, I4 ${ }^{\text {th }}$ October. Available in https://turnbackhoax.id/2017/10/14/ fitnah-jokowi-nama-lahirnya-herberthus/ (Accessed January 24, 2020)

"Hoaks Merusak Kualitas Pemilu [Hoax Damages the Election's Quality]", (2019), Kompas, $4^{\text {th }}$ January, p. I\&I5.

"Hoaks dan Ujaran Kebencian Jadi Teror Demokrasi Indonesia [Hoaxes and Hate Speeches Become Terror to Indonesian Democracy]. Dpr.go.id, 28/2/20I9. Available in http://www. dpr.go.id/berita/detail/id/24429/t/Hoaks+d an+Ujaran+Kebencian+jadi+Teror+Demok rasi+Indonesia (Accessed February 8, 2020).
"[Hoax] KTP Pemilih Digandakan untuk Orang yang Sama Beretnis China [Hoax, Voters Identity Cards Multiplied for a Person with Chinese Ethnic]", (2019), Turnbackhoax.id, 22 ${ }^{\text {nd }}$ February. Available in https:// turnbackhoax.id/2017/02/04/hoax-ktppemilih-digandakan-untuk-orang-yangsama-beretnis-china/ (Accessed January 25, 2020)

"Hoax". Merriam-webster.com. Available in https:// www.merriam-webster.com/dictionary/hoax (Accessed Februaty 3, 2020).

"Indonesia to Censor Social Media during Emergency", (2019), Thejakartapost.com, $29^{\text {th }}$ October. Available ini https://www. thejakartapost.com/news/2019/10/29/ blocked-and-reported-indonesia-to-censorsocial-media-during-emergencies.html (Accessed February 4, 2020)

"Internet Usage in Asia", 2019. Available in https:// www.internetworldstats.com/stats3.htm (Accessed January 28, 2020).

"Jakarta Riots Death Toll Rises to Eight, More than 700 Injured", (2019), Thejakartapost. com, $23^{\text {rd }}$ May. Available in https://www. thejakartapost.com/news/2019/05/23/ jakarta-riots-death-toll-rises-to-eight-morethan-700-injured.html (Accessed February $4,2020)$

"Jokowi Bicara Soal Hoax yang Terpa Dirinya kepada Santri [Jokowi Talks About Hoaxes Aimed at Him in front of Islamic Boarding School's Students]", (2018), Detik.com, $20^{\text {th }}$ October. Available in https://news.detik. com/berita-jawa-tengah/d-4265343/jokowibicara-soal-hoax-yang-terpa-dirinyakepada-santri (Accessed February 3, 2020)

"Kala Emosi Mendominasi [When Emotion Becomes Dominant]", (20I9), Kompas, $3^{\text {rd }}$ February, p. 2.

"Pemblokiran Dinilai Rugikan Masyarakat [Internet Shutdown Harms Societies]" (2019), Kompas, $23^{\text {rd }}$ August, p.8.

"Pemblokiran Masih Berlangsung di Papua dan Papua Barat [Internet in Papua and West Papua are Still Throttled]", (2019), Kompas, $26^{\text {th }}$ August, p.D.

"Presiden Ingin Polri Tuntaskan Isu Hoaks [Presidents Instruct The Indonesian National Police to Investigate Hoax]”, (20I8), Kompas, $7^{\text {th }}$ March, page. 3 . 
"[Salah] Kontainer Surat Suara yang Sudah Dicoblos [Wrong, Containers Consisting of Punched Ballot Papers]", (2019), Turnbackhoax.id, $3^{\text {rd }}$ January. Available in https://turnbackhoax. id/2019/01/03/salah-kontainer-surat-suarayang-sudah-dicoblos/ (Accessed February 3, 2020)

“[Salah] Pergerakan Mirip '98' [Wrong, 98's a Like Movements]", (2019), Turnbackhoax.id, $18^{\text {th }}$ April. Available in https://turnbackhoax. id/2019/04/18/salah-pergerakan-mirip-98/ (Accessed February 5, 2020)
"TNI Berkomitmen Jaga Persatuan dari Ancaman Hoaks [Indonesian Armed Forces is Commited to Protect Indonesian Unity from Hoax]", (2018), Kompas, $24^{\text {th }}$ July, p.4.

"Wiranto Ancam Penyebar Hoaks Pemilu Pakai UU Terrorisme [Wiranto Threatens Election Hoax Spreaders Using the Terrorism Law]", (2019), CNNIndonesia.com, $20^{\text {th }}$ March. Available in https://www.cnnindonesia.com/ nasional/20190320203726-32-379252/ wiranto-ancam-penyebar-hoaks-pemilupakai-uu-terorisme (Accessed January $26,2020)$ 